TITLE:

\title{
Progression of aortic regurgitation after subpulmonic infundibular ventricular septal defect repair(Abstract_要旨 )
}

AUTHOR(S):

Amano, Masashi

\section{CITATION:}

Amano, Masashi. Progression of aortic regurgitation after subpulmonic infundibular ventricular septal defect repair. 京都大学, 2020, 博士(医学)

ISSUE DATE:

2020-03-23

URL:

https://doi.org/10.14989/doctor.r13331

\section{RIGHT:}

This article has been accepted for publication in Heart 2016 following peer review, and the Version of Record can be accessed online at http://dx.doi.org/10.1136/heartjnl-2015-309005.๑ Authors 2016: Reuse of this manuscript version (excluding any databases, tables, diagrams, photographs and other images or illustrative material included where a another copyright owner is identified) is permitted strictly pursuant to the terms of the Creative Commons AttributionNon Commercial 4.0 International (CC-BY-NC 4.0) http://creativecommons.org

https://creativecommons.org/licenses/by-nc/4.0/ 


\begin{tabular}{|l|l|l|l|}
\hline 京都大学 & 博士 ( 医 学 $)$ & 氏 名 & 天 野 雅 史 \\
\hline \multirow{3}{*}{ 論文題目目 } & $\begin{array}{l}\text { Progression of aortic regurgitation after subpulmonic infundibular } \\
\text { ventricular septal defect repair } \\
\text { (肺動脈弁下漏斗部型心室中隔欠損症術後における大動脈弁逆流の進行) }\end{array}$
\end{tabular}
(論文内容の要旨)

【背景・目的】心室中隔欠損症（VSD）は最も多い先天性心疾患である。その中で肺動脈 下・漏斗部欠損型 VSD（VSDI 型）では、大動脈弁逆流症（AR）を伴うことが多く、進行性 であるため、AR や大動脈弁尖の変形を来たす前に VSD 閉鎖術を施行することが推奨され る。術前に中等度以上の AR を合併する場合、VSD 閉鎖術と同時に大動脈弁形成術を施行 するが、たとえ術直後にAR を認めない、もしくは微量であったとしても、これらの症例 では術後AR の増悪を認めることが多い。一方、術前 AR が軽度以下でVSD 閉鎖術のみを施 行し、かつ術直後の AR が微量以下であるにも関わらず、術後長期フォローアップ中に AR が進行する症例を認める。しかし、これらの症例における AR 進行の予測因子に関寸る知 見はほとんどない。本研究の目的は、VSDI 型に対する閉鎖術のみを施行した症例におけ る、術後晚期の AR 進行に関する発生頻度と予測因子を検討することである。【方法】 1972 年以降、天理よろつ相談所病院で VSDI 型と診断され閉鎖術を施行した連続 122 例を抽出 し、術後 3 年以上経てフォローアップ心エコー図検査が未施行である 22 例と閉鎖術と同 時に大動脈弁手術を施行した 9 例を除く 91 例を対象とした。VSD はSoto 分類を用いて分 類し、外科手術所見と照合して最終決定した。AR の重症度評価は経胸壁心エコ一図検查 によるカラドプラー法または心臓カテーテル検査における大動脈造影での半定量評価を 用いた。AR 進行の定義は、術後長期フォローアップ中にAR の重症度が中等度以上に増悪 するとした。【結果】術後フォローアップ期間の中央值は 13.4 年であり、全 91 例におけ る手術時年齢の中央值は 3 歳 (0-38 歳) で、男性が 60 例(67\%) であった。術後の AR 進行は 7 例 (7.7\%) で認め (AR 進行群)、84 例では認めなった(AR 非進行群)。両群間(AR 進行群 vs. AR 非進行群) で、手術時年齢 (4 vs. 3 歳; $\mathrm{p}=0.98)$ ・ 性別(男性) [5 (71) vs. $55(66 \%)$;

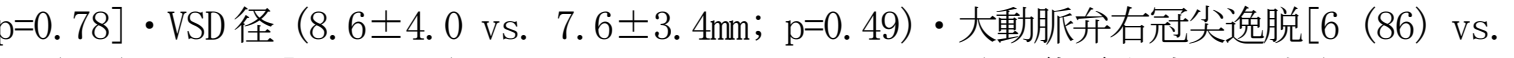
$52(63 \%) ; p=0.24] \cdot Q p / Q s(1.9 \pm 0.9$ vs. $1.7 \pm 0.9 ; p=0.46)$ ・術前左室駆出率 $(70 \pm 11$ vs. $67 \pm 24 ; \mathrm{p}=0.63)$ ・術前平均肺動脈圧 $(20.4 \pm 9.2$ vs. $21.0 \pm 12.7 ; \mathrm{p}=0.90)$ に有意差を認 めなかったが、術後の VSD リーク残存率には両群間で有意差を認めた $[3(43 \%)$ vs. 2 $(2.4 \%) ; \mathrm{p}<0.01]$ 。また、AR 進行群 7 例中、6 例で大動脈弁右冠尖の肥厚・硬化を認めた。 6 例中 5 例では、この右冠尖の変形により AR ジェットは、僧帽弁前尖方向(後方)、1 例で は右冠尖の変形に加え右冠尖弁葉全体が左室側に牽引されて中隔方向(前方)であった。右 冠尖の変形を伴わない残り 1 例では、右冠尖弁葉全体が左室側に牽引されることで僧帽弁 前尖方向(後方)のAR を認めた。【結論】VSDI 型患者において、VSD 閉鎖術のみ施行後の晚 期における AR 進行の発生率は、7.7\%であった。術後のVSD リークの存在が、VSD 閉鎖術 のみ施行後の晚期における AR 進行の重要な危険因子である可能性がある。たとえ、術前 AR が軽度でVSD 閉鎖術のみ施行した症例でも、術後 AR 進行に着目した長期フオローアッ プが必要である。

【考察】VSDI 型の自然閉鎖は稀で、AR の有無に関わらず大動脈弁右冠尖逸脱を認めるこ とが多い。この大動脈弁変形の進行には Venturi 効果が強く関わっている。VSDI 型の場 合、大動脈弁右冠尖の可動変曲部位が VSD 孔の上縁に近接するため、Venturi 効果の影響 が大きい、Venturi 効果以外の大動脈弁変形のリスク因子としては、弁葉支持組織の欠如、 弁尖同士の接合による支持減弱などがあげられる。本研究の結果から、VSD リークが VSD 閉鎖術後症例の AR 進行のリスク因子であり、これはリークに伴う Venturi 効果と同時に、 リーク血流に長年さらされることで弁尖の肥厚・萎縮が生じることが原因と考えられた。 一方、リークを認めない症例では、Venturi 効果以外の様々な要因が重なり、大動脈弁 右冠尖の変性が進むことでARが進行する。
（論文審査の結果の要旨）

本研究は、日本人に多く海外からの報告が少ない心室中隔欠損症(VSD) I 型に対寸る閉鎖 術のみを施行し術後フォローアップが可能であった 91 症例における、術後晚期の大動脈 弁逆流(AR) 進行に関する発生頻度とその予測因子を検討したものである。AR 進行の定義 は、術直後には軽度であった AR が術後晚期に中等度以上に増悪するとした。術後のAR 進 行は 7 例 (7. 7\%) で 認め(進行群)、84 例では認めなった(非進行群)。両群間で、年齢・性 別・VSD 径・大動脈弁右冠尖逸脱・Qp $/ \mathrm{Qs}$ ・術前左室駆出率・平均肺動脈圧に有意差を認 めなかったが、術後 VSD リーク残存率に有意差を認めた。また、AR 進行群 7 例中 6 例で 大動脈弁右冠尖の肥厚・硬化を認め、AR は 5 例で僧帽弁前尖方向(後方)、1 例では左冠尖 弁葉全体が左室側に牽引されて中隔方向(前方)に吹いた。右冠尖の変形を伴わない残り 1 例では、右冠尖弁葉全体が左室側に牽引され増帽弁前尖方向(後方)のAR 認めた。単施 設後ろ向き観察研究で、症例数が少なく AR の重症度を到達距離のみで決定している点な ど制約はあるが、VSDI 型単独術後晚期に 7.7\% で AR が進行し、VSD リークがそのリスク 因子となるため、術後長期に及ぶフォローアップが重要であるという結論が得られた。

以上の研究は、VSDI 型単独術後における AR 増悪の理解に貢献し、今後の VSDI 型患 者の術後フォローアップの重要性を臨床医が再認識するという点で寄与するところが多 w。

したがって、本論文は博士（医学 ）の学位論文として価值あるものと認める。

なお、本学位授与申請者は、令和 1 年 12 月 17 日実施の論文内容とそれに関連した 研究分野並びに学識確認のための試問を受け、合格と認められたものである。

要旨公開可能日： 年 月 $\quad$ 日 以降

